\title{
Scientists work with industry to safeguard food and water
}

\author{
W.R. GOMES \\ Vice President \\ Agriculture and Natural Resources
}

$\mathrm{D}$

uring the past year, we have explored five decades of

change in California and the Division, culminating with the special 50th anniversary issue of California Agriculture in November-December 1996. Now it's time to look ahead to the next 50 years, a period destined to bring even more dramatic change, much of it driven by a projected doubling of

California's population to 63 million by 2040 .

To serve those Californians, DANR scientists will increasingly operate at the intersection of food production, public health, and the environment, and their work will have direct implications for public policy. A current example is the Division's research and extension in foodborne and waterborne disease, efforts made more urgent by growing populations dependent on massive distribution systems for food and water.

Although the United States' food and water supplies are among the safest in the world, recent outbreaks of foodborne and waterborne disease have aroused nationwide concern and regulatory action. In this issue, UC scientists identify research priorities for two major disease-causing organisms: Escherichia coli O157:H7, primarily transmitted in food, and Cryptosporidium parvum, commonly transmitted in water (see page 8).

In 1993, C. parvum contaminated drinking water in Milwaukee, causing 403,000 illnesses and close to 100 deaths. Although the source was never identified, possibilities considered by investigators included cattle along the rivers flowing into the city's harbor, slaughterhouses and human sewage.

That same year, E. coli O157:H7 contaminated fast-food hamburgers from a Jack-in-the-Box restaurant in Washington state, leading to 700 illnesses and 4 deaths. More recently, last October, the same pathogen contaminated unpasteurized Odwalla apple juice and caused 67 illnesses and one death.

Disease outbreaks have led to regulatory reforms at the federal, state and local levels - and those reforms have implications for agriculture. In 1996, the Environmental Protection Agency (EPA) issued new rules and amendments to the Safe Drinking Water Act. Also in 1996, the U.S. Department of Agriculture announced a major overhaul of federal food safety rules for meat and poultry. In January 1997, President Clinton launched a new food safety initiative, promising further reforms.

In some cases, public concern has propelled regulations ahead of current scientific understanding. For instance, the new regulations call for increased sampling and testing, and improved control measures for foodborne and waterborne pathogens. Inspectors who find contaminated products at a processing plant may direct regulatory efforts upstream to the original producer. If there are known management practices which can eliminate a pathogen at the production level, it is reasonable to hold producers responsible. However, little is known at present about the medical ecology of C. parvum or

E. coli O157:H7, their sources, or how best to detect and control them. Neither cause symptoms in adult cattle, and there are no known drug treatments for $E$. coli $\mathrm{O} 157: \mathrm{H7}$, and only experimental protocols for treatment of $C$. paroum.

The need for a better understanding of these and other pathogens is urgent, as is the need for better testing, monitoring, prevention and control measures. Several studies addressing these issues are now underway, including projects by more than 20 UC Davis scientists spanning disciplines from veterinary medicine to agronomy and range science.

Some specific projects include:

- Research to estimate the prevalence of pathogens in livestock populations, and describe their ecology. Numerous pathogens are under study, including C. paroum and E. coli O157:H7.

- Research to identify best livestock management procedures for producers and the best post-slaughter practices for processors and distributors. Scientists are also conducting studies to identify major points of possible contamination in slaughter and processing plants.

- Research to bring new laser and microwave technologies to the farm to address concerns about milk quality, waste management, and water quality.

- Research to define how long C. paroum oocysts remain viable and under what conditions, and to evaluate how far oocysts are transported by natural rainfall.

California food producers and distributors, in partnership with $U C$, have become national leaders in developing hazard analysis and critical control points (HACCP) plans. In addition, many in the industry have developed more extensive Total Quality Management plans, which include procedures to improve nutritional quality of dairy and livestock products as well as programs to reduce pathogens.

Ultimately, improving food and water safety will require research and education at many points in the chain of events that occur from the time food is produced or water is collected to the time it reaches the consumer. For instance, educating consumers about steps they must take to prevent and control foodborne illness is a vital link in the food preparation chain.

California dairy production leads the nation, and livestock commodities consistently rank among the state's leading farm products. In 1995, farmers and ranchers produced $\$ 2.8$ billion worth of milk and cream, and $\$ 1.1$ billion worth of cattle and calves. Chicken eggs, chicken and turkey production are also significant economic contributors.

These robust industries are vital both as food producers and as guardians of our food and water quality. The challenge for the Division is to develop and extend research that will help sustain their vitality and viability, while protecting the nation's food and water supplies. 